\title{
Peningkatan hasil belajar siswa dengan menggunakan metode bermain peran dalam pembelajaran PKn
}

\author{
Sarniyati* \\ UPT. SDN 12 Air Pura \\ *) Correspondence e-mail: sarniyati@gmail.com
}

\begin{abstract}
The conditions of learning in elementary schools, especially Civics Education at this time still use a lot of conventional learning models (Lecture method). In learning, students only become objects, so it does not encourage the potential of students to develop. Civics Learning with the use of the role-playing method in grade V elementary school is very good to apply. It aims to make students able to portray something to the front of the class, have an attitude of respect for others, be creative, learn to solve a particular problem and be able to get along in a group environment and social life. The results showed that there was an increase in students' abilities in learning by using roleplaying. This is indicated by the increase in results in the form of grades obtained by students, namely the value in the first cycle based on the assessment of results with an average of 6.96. While the value of the implementation of learning in the second cycle increased by 8.57. At the learning planning stage, the teacher's ability to design learning plans increases. This is reflected in (1) the learning plan includes things that form the basis of planning, (2) the learning plan is prepared based on the education unit level curriculum by taking into account the interests and needs of students, (3) the learning plan has included learning tasks as a clear and detailed that supports the achievement of objectives.
\end{abstract}

Keywords: hasil belajar, metode bermain peran, pembelajan PKn

Article History: Received on 08/11/2019; Revised on 27/11/2019; Accepted on 12/12/2019; Published Online: 20/12/2019.

\section{INTRODUCTION}

Salah satu metode pembelajaran yang dianggap cocok diterapkan dalam PKn adalah metode Bermain Peran. Alasan pemilihan metode bermain peran karena pada metode ini menerapkan kemampuan dibidang afektif (sikap) siswa dalam kehidupan sehari-hari. Sejalan dengan tuntutan pembelajaran PKn yang menginginkan pengembangan sikap siswa baik dilingkungan rumah, sekolah, dan masyarakat. Menurut Syaiful (2008:11) "Bermain Peran (Role Playing) merupakan salah satu model pembelajaran yang diarahkan pada upaya pemecahan masalah-masalah yang berkaitan dengan hubungan antar manusia (Interpersonal Relatioship). Terutama yang menyangkut kehidupan siswa." 
Kenyataannya dalam proses pembelajaran PKn di UPT SDN 12 Air Pura Kecamatan Air Pura guru lebih dominan menggunakan metode ceramah, sedangkan tidak semua materi dapat diajarkan dengan menggunakan metode ceramah, akibatnya pembelajaran yang diberikan guru kurang menarik minat belajar siswa. Tuntutan pembelajaran PKn, guru seharusnya menggunakan metode yang yang menuntut sikap afektif siswa seperti metode bermain peran. Sedangkan guru jarang menggunakan metode nermain peran sehingga sikap afektif belum tertanam dalam diri siswa. Sesuai dengan Kurikulum Tingkat Satuan Pendidikan (KTSP) kelas V semester II, standar kompetensi 3. Memahami kebebasan berorganisasi dengan kompetensi dasar Menampilkan peran serta dalam memilih organisasi di sekolah. Salah satu metode yang dianggap cocok untuk pembelajaran ini adalah Metode bermain peran. Oemar (2003:48) menjabarkan bahwa : 1) Dalam Bermain Peran, siswa dapat bertindak dan mengekspresikan perasaan dan pendapatnya tanpa sanksi, 2) bermain peran memungkinkan dan memperkenankan siswa untuk mengidentifikasi situasi-situasi dunia nyata dan gagasan-gagasan lainnya. Berdasarkan hasil observasi saat pembelajaran PKn di UPT SDN 12 Air Pura Kecamatan Air Pura, terbukti bahwa pelaksanaan pembelajaran yang di lakukan guru dominan dengan metode berceramah, sehingga hasil pembelajaran kurang maksimal. Berdasarkan masalah di atas penulis tertarik untuk melakukan penelitian tindakan kelas dengan judul " Peningkatan Hasil Belajar siswa dengan Menggunakan Metode Bermain Peran dalam Pembelajaran PKn di Kelas V UPT SDN 12 Air Pura Kecamatan Air Pura Kabupaten Pesisir Selatan ".

\section{METHOD}

Penelitian dilaksanakan di UPT SDN 12 Air Pura Kecamatan Air Pura Kabupaten Pesisir Selatan. Subjek penelitian adalah siswa berjumlah 26 orang yang terdiri dari 15 orang perempuan dan 11 orang laki-laki. Pada dasarnya penelitian ini merupakan penelitian tindakan kelas dengan menggunakan pendekatan kualitatif. Jenis penelitian yang dilakukan merupakan penelitian tindakan kelas (action research) dibidang pendidikan dan pengajaran PKn. Dalam penelitian tindakan kelas diadakan perlakuan tertentu yang didasarkan pada masalah-masalah aktual yang ditemukan di lapangan. Penelitian ini dilakukan dengan menggunakan model siklus yang dikembangkan oleh Kemmis dan Mc Taggart (dalam Ritawati 2008:69 ), proses penelitian merupakan proses daur ulang atau siklus yang dimulai dari aspek : mengembangkan perencanaan, melakukan tindakan sesuai rencana, melakukan observasi terhadap tindakan dan melakukan refleksi terhadap perencanaan.

Data penelitian ini dikumpulkan dengan menggunakan, lembar observasi, wawancara dan hasil tes. Untuk masing-masingnya diuraikan sebagai berikut: Pada dasarnya berupa paparan tentang latar pengamatan terhadap tindakan praktis sewaktu pembelajaran PKn dengan menggunakan metode bermain peran. Unsur-unsur yang diamati dalam pelaksanaan mengacu pada apa yang tertera pada butir-butir lembar observasi. Di samping itu, juga memuat rancangan refleksi berdasarkan pengamatan yang dilakukan peneliti dengan cara observasi.

Data yang diperoleh dalam penelitian dianalisis dengan menggunakan analisis data kualitatif yang ditawarkan oleh Miles dan Huberman ( dalam Ritawati 2008:77-78 ) yakni 
analisis data dimulai dengan menelaah sejak pengumpulan data sampai seluruh data terkumpul. Data tersebut direduksi berdasarkan masalah yang diteliti, diikuti penyajian data dan terakhir pengumpulan data atau Verifikasi. Tahap analisis yang demikian dilakukan berulang-ulang begitu data selesai dikumpulkan pada setiap tahap pengumpulan data dalam setiap tindakan.

\section{RESUlTS AND DisCUSSION}

\section{Hasil Penelitian}

\section{Siklus I}

Pada siklus 1 ini, peneliti melakukan 2 kali pertemuan dengan materi yang diambil dari Kurikilum Tingkat Satuan Pendidikan yang kompetensi dasarnya menampilkan peran serta dalam memilih organisasi di sekolah, dimana dalam pelaksanaannya akan dipaparkan penggunaan metode bermain peran dalam perencanaan, pelaksanaan, dan hasil pembelajaran Pkn. Penggunaan ini akan terlihat dalam kegiatan Guru memiliki situasi bermain peran, Guru merancang skenario bermain peran, sebelum bermain peran siswa harus mengikuti latihan pemanasan, guru memberi instruksi khusus kepada peserta bermain peran, guru memberi tahu peran-peran yang akan dimainkan, para aktor melakukan perannya, bermain peran harus berhenti pada titik penting atau apabila terdapat tingkah laku yang menuntut dihentikannya permainan tersebut, keseluruha kelas berpartisipasi dalam diskusi yang berpusat pada bermain peran yang dilakukan, guru memberikan keterangan tentang keberhasilan dan hasil-hasil yang dicapai dalam bermain peran, Guru menulai efektifitas dan keberhasilan bermain peran, Guru membuat catatan tentang bermain peran yang telah bermain peran selanjutnya.

\section{Pelaksanaan siklus I pertemuan II}

Pelaksanaan pembelajaran pertemuan II pada penelitian ini juga melalui 3 tahap yakni tahap awal, tahap inti, tahap akhir. Dimana pada tahap inti dilaksanakan langkahlangkah metode bermain peran yaitu persiapan dan instruksi, tindak dramatik dan diskusi, evaluasi bermain peran. Pelaksanaannya sebagai berikut:

Tahap awal. Mengawali tindakan ini, peneliti mengucapkan salam yang dilanjutkan dengan menyiapkan kondisi kelas untuk belajar dengan memperhatikan kebersihan ruangan kelas, meminta siswa merapikan meja dan kursi "coba semua anak-anak ibu rapikan dulu tempat duduknya masing-masing!" dan siswa pun merapikan tempat duduknya masing-masing. Selanjutnya guru pun mempersiapkan alat dan bahan yang berhubungan dengan pembelajaran yang akan dilaksanakan.

Tahap inti. Kegiatan inti dilaksanakan sesuai dengan langkah-langkah metode bermain peran yang menurut Oemar (2008:215) adalah: 1) persiapan dan instruksi, 2) tindak dramatik dan diskusi, 3) evaluasi bermain peran.

Persiapan dan instruksi. Pelaksanaan tahap guru memiliki situasi bermain peran, langkah ini diawali dengan guru memilih masalah apa yang akan diperankan dalam bermain peran. Guru merancang skenario bermain peran, Sebelum bermain peran dilakukan terlebih dahulu guru sudah mempersiapkan skenario yang akan ditampilkan oleh siswa 
dalam bermain peran dan membagikan skenario cerita pada masing-masing siswa. Sebelum bermain peran,siswa harus mengikuti latihan bermain peran, Pada pertemuan II ini guru juga meminta siswa untuk melakukan latihan bermain peran sesuai dengan skenario cerita. agar siswa bisa memahami karakter tokoh yang ada dalam skenario ceria yang telah dibagikan pada setiap siswa dengan baik dan benar. Guru memberi instruksi khusus pada peserta bermaian peran, Pada langkah ini guru memberi tahu kepada siswa latar belakang masalah yang ada dalam skenario cerita dan siswa mendengarkan penjelasan guru dengan serius, Cara terbaik untuk memilih peseta bermain peranan atas dasar sukarela: siswa merasa bebas mendapat perannya.

Guru memberitahu peran-peran apa yang akan dimainkan, Pada tahap ini guru membagi siswa atas 4 kelompok kelompok pertama dan kedua berjumlah 7 orang dan kelompok ketiga dan keempat berjumlah 6 orang, jumlah seluruh siswa adalah 26 orang.tokoh yang berperan seluruhnya untuk kelompok satu dan dua berjumlah 7 orang sedangkan untuk kelompok tiga dan empat berjumlah 6 orang dengan skenario yang sama.

Tindak dramatik dan diskusi. Para aktor melakukan perannya, Pada tahap ini guru meminta kelompok pertama memainkan peran sesuai skenario cerita dan siswa yang lain mengamati. Setelah kelompok pertama selesai memainkan perannya guru meminta siswa yang bermain peran memberikan tanggapan tentang perannya.

Guru meminta kelompok dua memainkan peran sesuai dengan skenario cerita dan siswa yang lain mengamati. Setelah kelompok kedua selesai memainkan perannya guru meminta siswa yang bermain peran memberikan tanggapan tentang perannya. Pada umumnya seluruh anggota kelompok dua memberikan tanggapan mereka serius dalam melakukan bermain peran.

Guru meminta kelompok tiga memainkan peran sesuai dengan skenario cerita dan siswa yang lain mengamatinya.setelah kelompok tiga selesai bermain peran siswa yang bermain peran diminta memberikan tanggapan tentang perannya, pada umumnya anggota kelompok tiga memberikan tanggapan bahwa mereka telah memahami karakter dari masing-masin tokoh yang ada dalam skenario cerita hanya saja mereka kurang serius dalam melakukan bermain peran.

Kelompok empat diminta memainkan perannya sesuai dengan skenario cerita dan siswa yang lain mengamatinya. Setelah kelompok empat selesai bermain peran siswa yang bermain peran diminta memberikan tanggapan tentang perannya, pada umumnnya mereka memberikan tanggapan bahwa mereka telah memahami skenario cerita dan telah bermain peran dengan serius dan tidak malu-malu dalam melakoni tokoh yang ada dalam skenario cerita.

Bermain peran harus berhenti pada titik penting, langkah ini dilakukan apabila ada sikap atau tingkah laku menyimpang dari anggota bermain peran. Contoh nya pada waktu kelompok tiga tampil guru harus memberhentikan bermain peran karna ada anggota kelompok tiga yang kurang serius dalam bermain peran sehingga membuat suasana kelas ribut. Keseluruhan kelas berpartisipasi dalam diskusi yang berpusat pada bermain peran yang telah dilakukan, Setelah bermain peran dilakukan, guru dan siswa bertanya jawab tentang manfaat organisasi sekolah yang telah diperankan. Dan kemudian guru menyuruh siswa duduk dalam kelompoknya masing-masing untuk 
melakukan diskusi dalam kelompoknya tentang siapa-siapa saja nama tokoh yang ada dalam skenario serta bagimana karakter dari masing-masing tokoh.

Evaluasi bermain peran. Guru memberikan keterangan tentang keberhasilan dan hasil-hasil yang dicapai dalm bermain peran, Setelah diskusi dilakukan masing-masing dari perwakilan kelompok diminta untuk melaporkan hasil diskusinya kedepan kelas dan kemudian memberiksn tanggapan tentang hasil diskusi lalu siswa secara klasikal menyimpulkan jawaban yang tepat dari hasil diskusi tersebut. Pada tahap ini guru juga guru juga memberikan penilaian terhadap bermain peran yang telah dilakukan, apakah tingkat perkembangan pribadi, sosial, dan akademiknya sesuai dengan yang diharapkan. Guru menilai keektivitas dan keverhasilan bermain peran, Pada tahap ini guru membuat catatan-catatan selama bermain peran dilakukan serta komentar penilaian dari siswa. Guru membuat catatan tentang bermain peran yang telah dilakukan, Dalam tahap ini guru memasukkan skenario bermain peran yang telah dilakukan pada buku catatan guru yang bertujuan untuk perbaikan bermain peransselanjutnya.

Tahap akhir. Guru mengarahkan siswa pada pertanyaan-pertanyaan yang membawa siswa menyimpulkan sendiri pengetahuan yang mereka peroleh dari pembelajaran mengenai organisasi koperasi sekolah. Kemudian guru memberikan latihan berupa soalsoal kepada siswa

\section{Pengamatan tindakan siklus I pertemuan II}

Pada tahap ini pengamatn dilakukan oleh obsever, yaitu peneliti ssebagai obsever pertama dan dibantu oleh guru kelas yang bersangkutan sebagai pengamat I, dan seorang teman sejawat sebagai pengamat II. Masing- masing pengamat mempunyai tugas yang sama. Yaitu mengamati aktivitas praktisi dalam pembelajaran dengan menggunakan lembar observasi guru dan siswa, selain itu peneliti juga dibantu oleh satu teman lainnya yang bertugas mendokumentasikan semua langkah-langkah pembelajaran yang peneliti lakukan selama menjadi guru praktisi dalm proses pembelajaran

Pada tahap ini kegiatan yang dilakukan oleh kedua pengamat adalah mengamati jalannya kegiatan pembelajaran menggunakan lembaran pengamatan yang telah disediakan. Aspek yang diamati adalah:

Dari segi pelaksanaan guru dan siswa. Hasil pengamatan yang dilakukan obsever selama pelaksanaan pembelajaran berlangsung dengan menggunakan metode bermain peran. Pada pertemuan I adalah dari kualifikasi guru baru mencapai kategori cukup sedangkan dari kualifikasi siswa juga dikategorikan cukup. Untuk lebih jelasnya hasil pengamatan yang diperoleh pada pertemuan I ini terdapat pada lampiran.hasil data observasi pelaksanaan secara umum juga dapat dilihat pada lampiran. Pada pertemuan II ini aktifitas guru dan siswa sudah mulai baik dari pertemuan I namun hasil yang didapat masih kurang.

Dari segi aktifitas siswa. Dari segi aktifitas siswa, pengamat melaporan sebagai berikut: siswa kurang aktif untuk mengikuti pembelajaran, hal ini dapat dilihat bahwa siswa belum maksimal dalam bermain peran yang telah dilakukan, dan selama pembelajaran berlangsung siswa dapat dikatakan antusias dan semangat untuk belajar. 
Siswa bekerja dalam kelompok dengan sangat baik tetapi tidak semua siswa serius dalam melakukan diskusi, masih didominasi oleh siswa yang pintar dalam mengisi LKS hal ini terbukti saat guru bertanya pada salah seorang siswa bahwa dia tidak ikut mengisi LKS. Pada saat siswa disuruh dalam melaporkan hasil diskusi tidak mau kedepan kelas karena malu dan akhirnya ditunjuk salah satu siswa untuk melaporkan kedepan kelas. Setelah masing-masing kelompok melaporkan hasil diskusinya kedepan kelas, guru memberikan penghargaan kepada kelompok yang memperoleh nilai paling tinggi dibanding dengan kelompok yang lain.

Refleksi. Pada penilaian penggunaan metode bermain peran dilakukan dengan memberikan tes secara individual. Tes tersebut berupa soal yang dibagikan oleh guru. Sedangkan siswa hanya menulis jawabannya di bawah soal tersebut. Setelah diperiksa, ternyata masih ada siswa yang mendapat nilai dibawah rata-rata, yaitu nilai dengan angka 5. Dari keseluruhan pelaksanaan pembelajaran pada langkah-langkah siklus I, Nilai rata-rata yang didapatkan siswa secara keseluruhan adalah 6,48.

Dari hasil diskusi dengan guru kelas, maka diperoleh hal-hal sebagai berikut: 1) Waktu bermain peran terlalu sedikit; 2) Anak masih susah melafalkan dialog teks koperasi sekolah; 3) Hasil dialog koperasi sekolah yang diperoleh siswa sedikit memuaskan berada pada taraf sedang.

Berdasarkan pengamatan, wawancara, tes dan pencatatan lapangan maka tujuan pembelajaran yang diharapkan pada pembelajaran siklus I belum tercapai dengan baik. Dengan demikian upaya yang telah dilaksanakan pada penggunaan metode bermain peran pada siklus I dapat digunakan sebagai acuan untuk menentukan langkah-langkah proses pembelajaran yang akan ditargetkan pada siklus II.

\section{Siklus II}

Penggunaan metode bermain peran dalam pembelajaran PKn pada siklus II dilaksanakan setetah hasil refleksi siklus I. Dari hasil siklus I disusun perencanaan dan tindakan siklus II yang dilaksanakan sebanyak satu kali pada tanggal 4 juni 2019.data perencanaan dan tindakan dapat dipaparkan sebagai berikut:

Perencanaan. Penggunaan metode bermain peran dalam perencanaan pembelajaran PKn disusun dan diwujudkan dalam bentuk rencana pelaksanaan pembelajaran (RPP). Perencanaan yang dibuat pada siklus II ini pada umumnya sama dengan perencanaan pembelajaran pada siklus I. Perbedaannya dapat dilihat dari meteri, karna materi pada siklus II ini adalah materi lanjutan dari siklus I.

\section{Pelaksanaan siklus II}

Tahap awal. Menawali tindakan ini, peneliti mengucapkan salam yang dilanjutkan dengan menyiapkan kondisi kelas untuk belajar dengan memperhatikan kebersihan ruangan kelas, meminta siswa merapikan meja dan kursi "coba semua anak-anak ibu rapikan dulu tempat duduknya masing-masing!" dan siswa pun merapikan tempat duduknya masingmasing. Selanjutnya guru pun mempersiapkan alat dan bahan yang berhubungan dengan pembelajaran yang akan dilaksanakan. 
Tahap inti. Kegiatan inti dilaksanakan sesuai dengan langkah-langkah metode bermain peran yang menurut Oemar (2008:215) adalah: 1) Persiapan dan instruksi, 2) Tindak dramatik dan diskusi, 3) Evaluasi bermain peran.

Persiapan dan instruksi. Pelaksanaan tahap guru memiliki situasi bermain peran, Langkah ini diawali dengan guru memilih masalah apa yang akan diperankan dalam bermain peran. Guru merancang skenario bermain peran, Sebelum bermain peran dilakukan terlebih dahulu guru sudah mempersiapkan skenario yang akan ditampilkan oleh siswa dalam bermain peran dan membagikan skenario cerita pada masing-masing siswa. Sebelum bermain peran,siswa harus mengikuti latihan bermain peran, Pada siklus II pertemuan I ini guru juga meminta siswa untuk melakukan latihan bermain peran sesuai dengan skenario cerita.

Guru memberi instruksi khusus pada peserta bermaian peran, Pada langkah ini guru memberi tahu kepada siswa latar belakang masalah yang ada dalam skenario cerita dan siswa mendengarkan penjelasan guru dengan serius, Cara terbaik untuk memilih peseta bermain peranan atas dasar sukarela: siswa merasa bebas mendapat perannya.

Guru memberitahu peran-peran apa yang akan dimainkan, Pada tahap ini guru membagi siswa atas 5 masing-masing kelompok berjumlah 5 orang namun ada satu kelompok yang berjumlah 6 orang dengan skenario yang sama, jumlah seluruh siswa adalah 26 orang. Setelah guru membagi kelompok barulah guru memberitahu peranperan apa saja yang akan dimainkan yang ada dalam skenario, kemudian guru menjelaskan bagaimana peranan tokoh sesuai dengan peran yang telaha dibagi dan siswa mendengarkan penjelasan guru.

Tindak dramatik dan diskusi. Para aktor melakukan perannya, Pada tahap ini guru meminta kelompok pertama memainkan peran sesuai skenario cerita dan siswa yang lain mengamati. Setelah kelompok pertama selesai memainkan perannya guru meminta siswa yang bermain peran memberikan tanggapan tentang perannya.

Bermain peran harus berhenti pada titik penting, Langkah ini dilakukan apabila ada sikap atau tingkah laku menyimpang dari anggota bermain peran.

Evaluasi bermain peran. Guru memberikan keterangan tentang keberhasilan dan hasil-hasil yang dicapai dalm bermain peran, Setelah diskusi dilakukan masing-masing dari perwakilan kelompok diminta untuk melaporkan hasil diskusinya kedepan kelas dan kemudian memberiksn tanggapan tentang hasil diskusi lalu siswa secara klasikal menyimpulkan jawaban yang tepat dari hasil diskusi tersebut. Pada tahap ini guru juga guru juga memberikan penilaian terhadap bermain peran yang telah dilakukan, apakah tingkat perkembangan pribadi, sosial, dan akademiknya sesuai dengan yang diharapkan. Guru menilai keektivitas dan keverhasilan bermain peran, Pada tahap ini guru membuat catatan-catatan selama bermain peran dilakukan serta komentar penilaian dari siswa. Guru membuat catatan tentang bermain peran yang telah dilakukan, Dalam tahap ini guru memasukkan skenario bermain peran yang telah dilakukan pada buku catatan guru yang bertujuan untuk perbaikan bermain peran selanjutnya.

Tahap akhir. Guru mengarahkan siswa pada pertanyaan-pertanyaan yang membawa siswa menyimpulkan sendiri pengetahuan yang mereka peroleh dari pembelajaran mengenai 
pemilihan ketua kelas. Kemudian guru memberikan latihan berupa soal-soal kepada siswa

\section{Pengamatan tindakan siklus II}

Observasi keberhasilan tindakan diamati selama dan sesudah tindakan dilaksanakan. Hal ini dilaksanakan untuk mendapatkan informasi dari siswa dan obsever terhadap pelaksanaan pembelajaran dari siklus II. Informasi ini didapatkan melalui pengamatan dan wawancara dengan siswa dan obsever pada saat pembelajaran berakhir.

Pada tahap ini kegiatan yang dilakukan oleh kedua pengamat adalah mengamati jalannya kegiatan pembelajaran menggunakan lembaran pengamatan yang telah disediakan. Aspek yang diamati adalah:

Dari segi pelaksanaan guru dan siswa. Hasil pengamatan yang dilakukan obsever selama pelaksanaan pembelajaran berlangsung dengan menggunakan metode bermain peran. Pada siklus II adalah dari kualifikasi guru baru mencapai kategori baik sedangkan dari kualifikasi siswa juga dikategorikan baik. Ini menunjukkan bahwa pelaksanaan pembelajaran pada siklus II sudah mencapai tujusn yang diharapkan.Untuk lebih jelasnya hasil pengamatan yang diperoleh pada siklus II ini terdapat pada lampiran. Berikut hasil data observasi pelaksanaan secara umum.

Dari segi aktifitas siswa. Dari segi aktifitas siswa, pengamat melaporan sebagai berikut: siswa aktif untuk mengikuti pembelajaran, hal ini dapat dilihat bahwa siswa sudah maksimal dalam bermain peran yang telah dilakukan, dan selama pembelajaran berlangsung siswa dapat dikatakan antusias dan semangat untuk belajar.

Siswa bekerja dalam kelompok dengan sangat baik dan semua siswa serius dalam melakukan diskusi. Pada saat siswa disuruh dalam melaporkan hasil diskusi sebagian siswa menunjuk tangan untuk menuluskan kedepan. Hal ini membuktikan siswa sudah aktif untuk mengikuti pembelajaran.

Hasil tes menggambarkan bahwa subjek penelitian menguasai dengan baik materi tentang pemilihan ketua kelas dengan menggunakan metode bemain peran. Siswa memperoleh skor masing-masing diatas 100. tetapi ada 3 orang siswa diantaranya masih ada yang mendapat nilai dibawah 70 . Berdasarkan hasil tes akhir pada siklus II telah mencapai target, maka penelitian ini tidak dilanjutkan kepada siklus III.

Tahap analisis dan refleksi.

Berdasarkan penelitian, terlihat peningkatan yang terjadi pada siswa. Hal itu dapat dilihat dari beberapa hal yang ada dibawah ini: 1) Keberhasilan guru, (guru sudah lebih leluasa menyampaikan dan menggunakan langkah-langkah dalam pembelajaran, penggunaan waktu dalam pembelajaran pun sudah maksimal, setiap kelompok dapat dibimbing dengan baik); 2) Keberhasilan siswa (keaktifan siswa sudah terlihat dengan baik, siswa yang ditunjuk bersedia dengan senang hati untuk tampil ke depan kelas melaporkan hasil diskusinya, nilai yang didapat siswa sudah menampakkan hasil yang memuaskan, baik nilai disaat proses pembelajaran maupun diskusi kelompok dan nilai tes akhir serta ketuntasan belajar siswa). 


\section{Pembahasan}

Pada bagian ini dilakukan pembahasan hasil penelitian yang telah dipaparkan di atas. Pembahasannya adalah peningkatan hasil belajar siswa dengan menggunakan metode bermain peran dalam pembelajaran PKn di kelas V UPT SDN 12 Air Pura Kecamatan Air Pura Pesisir Selatan. Dari fokus bahasan tersebut kemudian dibahas implikasi hasil penelitian bagi pengembangan pembelajaran PKn.

\section{Pembahasan Siklus I}

Dari analisis penelitian siklus I nilai rata-rata kelas baru mencapai 6,96. Berdasarkan hasil pengamatan siklus I yang diperoleh maka direncanakan untuk melakukan siklus II. Guru harus dapat memperhatikan perbedaan yang ada pada siswa karena tiap individu mempunyai karakteristik yang berbeda. Menurut Rochman Natawijaya (dalam Rosna, 2006:43) "Belajar adalah proses pembinaan yang terus menerus terjadi dalam diri individu yang tidak ditentukan oleh unsur keturunan, tetapi lebih banyak ditentukan oleh faktor-faktor dari luar anak." Dalam belajar siswa banyak memperoleh dari guru, maka guru harus lebih memahami kembali ketiga aspek dalam pendidikan yaitu yang belajar, proses belajar dan situasi belajar. Yang belajar adalah anak didik atau siswa yang secara individu atau kelompok mengikuti proses pembelajaran dalam suasana tertentu.

Guru sebagai penggerak dan pengatur proses pembelajaran sudah seharusnya dapat mengaktifkan semua siswa tanpa terkecuali agar potensi memberikan motivasi kepada siswa dalam pembelajaran.

Peran guru dalam memberikan motivasi anak adalah "Mengenal setiap siswa yang diajarkannya secara pribadi, memperlihatkan interaksi yang menyenangkan, menguasai berbagai metode dan teknik mengajar serta menggunakannya dengan tepat, menjaga suasana kelas supaya siswa terhindar dari konflik dan frustasi serta yang amat penting memperlakukan siswa sesuai dengan keadaan dan kemampuannya."

\section{Pembahasan Siklus II}

Pembelajaran tentang pemilihan ketua kelas dengan menggunakan metode bermain peran pada siklus II ini sudah berjalan dengan baik, walau masih ada beberapa orang siswa yang belum dapat menyelesaikan soal yang diberikan dengan baik. Cara guru dalam membimbing siswa berdiskusi sudah cukup merata. Begitu juga dalam hal menunjuk siswa untuk melaporkan hasil diskusi ke depan kelas, juga sudah merata di seluruh siswa.

Dari hasil analisis penelitian siklus II sudah mencapai 85,7 \% dan nilai rata-rata kelas 8,57 Berdasarkan hasil pengamatan siklus II yang diperoleh, maka pelaksanaan siklus II sudah baik dan guru sudah berhasil dalam usaha peningkatan hasil belajar siswa dalam pembelajaran pemilihan ketua kelas dengan menggunakan metode bermain peran bagi siswa kelas V UPT SDN 12 Air Pura Kecamatan Air Pura Kabupaten Pesisir Selatan.

Pembelajaran yang disajikan guru pada siklus II sangat baik. Pada proses pembelajaran guru banyak memberikan kesempatan kepada siswa untuk berdiskusi bersama dan bertanya tentang permasalahan yang tidak dimengerti siswa. Untuk itu guru harus mampu menciptakan situasi yang meyenangkan untuk belajar. 
Untuk mencapai hal tersebut sudah seharusnya guru mampu menciptakan pembelajaran yang sesuai dengan kebutuhan siswa. Selain itu, guru juga harus memperhatikan keberhasilan siswa dalam memahami sesuatu dengan cara sesuai dengan tingkat kemampuan siswa. Karena guru bertugas membelajarkan siswa. Untuk membelajarkan siswa tersebut guru haruslah menggunakan berbagai macam cara agar pembelajaran dapat bermakna bagi siswa, seperti menggunakan model pembelajaran yang bervariasi, media pembelajaran yang sesuai dengan tujuan dan menciptakan suasana belajar yang menyenagkan bagi siswa.

\section{CONCLUSIONS}

Dari paparan data dan hasil penelitian serta pembahasan di atas, maka peneliti dapat menarik kesimpulan dari penelitian ini yakni: 1) Pembelajaran dengan menggunakan metode bermain peran sangat baik dilaksanakan untuk meningkatkan hasil belajar siswa, baik dalam hal kretifitas, kerjasama dalam kelompok, pemecahan masalah maupun pergaulan dalam kehidupan sosialnya; 2) Dalam pelaksanaan metode bermain peran ini, guru membagi siswa atas 4 kelompok yang masing-masing kelompok memainkan peranan yang sama, yaitu sebagai tokoh yang ada dalam skenario cerita; 3) Guru melakukan penilaian terhadap kegiatan siswa dalam melakukan pembelajaran bermain peran dan penilaian hasil tes akhir berupa lembaran soal yang dibagikan; 4) Dengan menggunakan metode ini, siswa sudah mulai cenderung untuk aktif dalam pembelajaran. Apalagi dengan menggunakan metode bermain peran ini, nantinya guru akan memberikan penghargaan kepada siswa yang memperoleh nilai yang tertinggi; 5) Meningkatnya hasil belajar siswa tersebut dapat dilihat dari rata-rata yang diperoleh pada siklus I yakni 6,96 dan mengalami peningkatan pada siklus II yakni 8,57. Hal ini merupakan bukti keberhasilan pelaksanaan penelitian yang telah dilakukan di UPT SDN 12 Air Pura Kecamatan Air Pura Kabupaten Pesisir Selatan.

\section{REFERENCES}

Aristo Rahadi. (2003). Media Pembelajaran .Jakarta: Depdiknas

Azis Toyibin, dkk, (1997). Pendidikan Pancasila. Jakarta : Rineka Cipta.

Azis Wahab. (1999). Pendidikan Pancasila dan Kewarganegaraan. Jakarta: Universitas Terbuka.

Depdiknas. (2006). Panduan Penyusunan Kurikulum Tingkat Satuan Pendidikan Jenjang Pendidikan Dasar dan Menengah. Jakarta: Depdiknas

M. ngalim. (2006). Prinsip-prinsip dan Teknik Evaluasi Pengajaran. Bandung: PT Remaja Rosdakarya

Nana Sudjana. (1996). Cara Belajar Siswa Aktif Dalam Proses Belajar Mengajar. Bandung: Sinar Baru Algensindo

Nana Sudjana. (2004). Penilaian Hasil Proses Belajar Mengajar.Bandung: PT Remaja Rosdakarya

Nuryani R. (2005). Strategi Belajar Mengajar Biologi. Malang: Universitas negeri malang. Oemar Hamalik. (2003). Pendekatan Baru Strategi Belajar-mengajar Berdasarkan CBSA . Bandung: Sinar Baru Algensindo 
Oemar Hamalik. (2005). Perencanaan Pengajaran Berdasarkan Pendekatan Sisitem. Jakarta: Bumi Aksara

Oemar Hamalik. (2008) . Proses Belajar Mengajar. Jakarta: Bumi Aksara.

Ritawati Mahyuddin, dkk. (2008). Hand Out Mata Kuliah Metodologi Penelitian Tindakan Kelas.Padang:UNP

Rochman Natawijaya. (1997). Psikologi Pendidikan. Jakarta: Debdikbud

Syaiful Bahri Djamarah, dkk. (2006). Strategi Belajar Menajar.Jakarta: Rineka Cipta

Udin S. Winataputra, dkk. (2006). Materi Pembelajaran PKn SD. Universitas Terbuka: Jakarta

Wina Sanjaya. (2008). Strategi Pembelajaran. Jakarta : Kencana

Zahara Djafar. (2001). Konstribusi Strategi Pembelajaran Terhadap Hasil Belajar. Padang: Fip UNP 